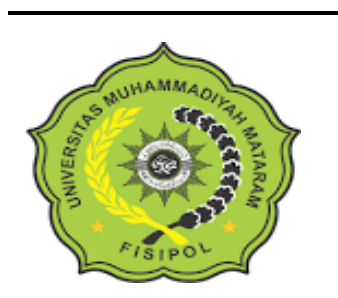

Journal of Government and Politics (JGOP) ISSN:2686-3391

Vol. 1 No. 2 Desember 2019

Journal of Government and Politics

(JGOP)

http://journal.ummat.ac.id/index.php/jsip

\title{
Peran Pemerintah Kabupaten Lombok Tengah Dalam Kegiatan Promosi Pariwisata Pasca Gempa Lombok
}

\author{
Lalu Muhamad Saleh ${ }^{1}$ Darmansyah $^{2}$ Azwar Subandi ${ }^{3}$ \\ ${ }^{123}$ Universitas Muhammadiyah Mataram
}

\section{InfoArtikel}

Sejarah Artikel:

Diterima: 14 Agustur 2019

Disetujui: 20 Desember 2019

Dipublikasikan : 20

Desember 2019

Kata Kunci :

Promosi Wisata; Pasca

Gempa Lombok; Peran
Abstrak

Pemerintah Kabupaten Lombok Tengah sesuai dengan asas otonomi daerah memberikan kewenangan, tugas dan fungsi kepada Dinas Pariwasata dan kebudayaan Kabupaten Lombok Tengah untuk malakukan perencanaan, pengendalian, pengawasan, dan pengorganisasian di bidang pariwisata. Penelitian ini bertujuan untuk menganalisis Peran Dinas Pariwisata Kabupaten Lombok Tengah pasca gempa lombok, dan apa saja faktor penghambat Kegiatan Promosi Pariwisata Pasca Gempa Lombok. Penelitian ini menggunakan metode deskriptif kualitatif dengan metode pengumpulan data observasi, dokumentasi dan wawancara. Hasil penelitian ini ditemukan bahwa Peran Dinas Pariwisata dan Kebudayaan Kabupaten Lombok Tengah dalam Kegiatan Promosi Pariwisata sudah dilaksanakan berdasarkan fungsi dan kewenangan yang dimiliki yang berlandaskan otonomi daerah. Setelah terjadinya gempa sebesar 7.0 Skala likter di pulau lombok banyak wisatawan yang keluar dan pergi dari pulau lombok karena akibat gempa yang terjadi. Dinas Pariwisata dan kebudayaan Kabupaten Lombok Tengah mulai berbenah dengan melakukan pengecekan kepada seluruh tempat wisata yang ada di Kabupaten Lombok Tengah, baik itu wisata alam maupun wisata buatan agar diketahui apakah ada yang rusak baik itu objek wisatanya maupun sarana dan prasarana penunjang atraksi wisata. 


\title{
ROLE OF CENTRAL LOMBOK DISTRICT GOVERNMENT IN POST- EARTHQUAKE LOMBOK TOURISM PROMOTION ACTIVITIES
}

\begin{abstract}
The Central Lombok Regency Government complies with the principle of regional autonomy to give authority, duties and functions to the Office of Pariwasata and the culture of Central Lombok Regency to carry out planning, control, supervision and organization in the tourism sector. This study aims to analyze the role of the Central Lombok Tourism Office after the Lombok earthquake, and what are the inhibiting factors of the Lombok Post-Earthquake Promotion Promotion Activity. This research uses descriptive qualitative method with the method of collecting observation, documentation and interviews. The results of this study found that the role of the Central Lombok District Tourism and Culture Office in Tourism Promotion Activities has been carried out based on the functions and authorities possessed based on regional autonomy. After the earthquake of 7.0 scale likter on Lombok island, many tourists left and left the island of Lombok because of the earthquake. The Central Lombok Regency Tourism and Culture Office began to clean up by checking all tourist attractions in Central Lombok Regency, both natural and artificial tourism so that it was known whether there were damaged tourism objects or tourist facilities and infrastructure..
\end{abstract}




\section{PENDAHULUAN}

Indonesia merupakan negara yang memiliki berbagai pulau besar dan kecil serta memiliki kekayaan alam dan potensi yang berbeda. Berbagai macam kekayaan alam tersebut dapat di kekola dengan baik untuk kepentingan negara. Berbagai kekayaan alam yang dimiliki oleh Indonesia ada yang dapat diperbaharui dan ada yang tidak dapat diperbaharui. Salah satu kekayaan alam Indonesia yang menarik pemerintah dan investor untuk mengelolanya karena memberikan keuntungan yang sangat besar untuk negara dalam bentuk pajak adalah di bidang pariwisata.

Pariwisata merupakan salah satu sektor unggulan yang terus di kembangkan oleh pemerintah pusat dan daerah sampe saat ini sebagai gagasan utama untuk menambah APBN dan pembangunan. Adanya pariwisata yang telah di kembangkan oleh pemerintah pusat dan daerah dapat memberikan kontribusi terhadap peningkatan pertumbuhan ekonomi masyarakat. Hal itu tentunya akan meningkatkan kesejahteraan masyarakat di sekitar lokasi pariwisata serta memberikan keuntungan bagi pemerintah pusat dan daerah.

Indonesia memiliki banyak sekali destinasi (tujuan) wisata yang menarik dan indah dipandang mata, seperti misalnya Bali dengan pantai Kutanya, juga Magelang di Jawa Tengah dengan Candi Borobudurnya serta Jakarta dengan Tugu Monasnya dan lain sebagainya. Tak heran jika para turis lokal maupun mancanegara berbondong-bondong datang ke Indonesia untuk rekreasi karena panorama yang dimilikinya, selain itu juga ragam budayanya yang memiliki nilai nilai luhur tersendiri. Sumber: (Ricky Febriansyah dkk, ejournal fisip unmul 2017).

Indonesia terkenal dengan berbagai budaya dan adat istiadat yang berbeda yang memberikan keragaman pada Indonesia sendiri. Adanya keragaman kebudayaan yang dimiliki oleh Indonesia membuat wisatawan makin banyak yang berkunjung ke Indonesia. Selain memiliki kebudayaan yang beragam Indonesia juga memiliki ke indahan alam yang tak terhingga membuat hampir seluruh wisatawan internasional memberikan rasa kagum tak terhingga dan kembali berkunjung ke Indonesia.

Pengelolaan Pariwisata di Indonesia harus dikelola dengan baik sesuai dengan tujuan negara dalam Undang-Undang Dasar Negara Republik Indonesia Tahun 1945, yaitu untuk melindungi segenap bangsa dan seluruh tumpah darah Indonesia dan memajukan kesejahteraan umum. Untuk pengelolaan pariwisata di Indonesia pemerintah menggunakan asas otonomi 
daerah sesuai dengan Undang-Undang Nomor 23 Tahun 2014 tentang Otonomi daerah dengan memberikan hak dan kewenangan kepada pemerintah daerah untuk mengelola parwisata yang ada di daerah dengan mementingkan kepentingan pemerintah daerah dan masyarakat.

Sektor pariwisata merupakan alternatif pemasukan bagi pendapatan daerah maupun bagi devisa negara, bahkan bagi negara-negara maju sekalipun pariwisata serius untuk dikembangkan. Terkait dengan hal itu, dalam Undang Undang Republik Indonesia No 9 Tahun 1990 menyatakan bahwa kepariwisataan mempunyai peranan penting untuk memperluas dan memeratakan kesempatan berusaha dan lapangan kerja, mendorong pembangunan daerah, memperbesar pendapatan nasional dalam rangka meningkatkan kesejahteraan dan kemakmuran rakyat serta memupuk rasa cinta tanah air, memperkaya kebudayaan nasional dan memantapkan pembinaannya dalam rangka memperkukuh jati diri bangsa dan mempererat persahabatan antar bangsa. Sumber (Farida Robithoh Widyasti, 1:2013).

Kabupaten Lombok Tengah adalah salah satu Kabupaten yang ada di Nusa Tenggara Barat. Kabupaten Lombok Tengah memiliki beragam tempat pariwisata mulai dari Desa Sade yaitu Desa Adat yang menarik wisatawan lokal dan mancanagara untuk berkunjung ke Desa Sade karena di Desa Sade masih murni masyarakat menggunakan adat sasak untuk beraktivitas sehari-hari seperti menenun dan menjual hasil tenunan pada wisatawan yang datang berkunjung.

Selain Desa Sade yang merupakan desa adat Kabupaten Lombok Tengah juga memiliki pantai pasir putih yang memiliki air jernih yaitu pantai kuta yang menarik perhatian wasatawan nasional dan mancanegara untuk datang berkunjung di Kabupataten Lombok Tengah. Peran pemerintah Kabupaten Lombok Tengah tentunya sangat penting untuk memajukan dan mengembangkan potensi pariwisata yang ada di Kabupaten Lombok Tengah.

Pengembangan pariwisata yang baik tentu akan memberikan manfaat yang begitu besar untuk pemerintah dan masyarakat yang ada di Kabupaten Lombok Tengah. Pemasukkan dari sisi pajak dan perijinan serta pemanfaatan lokasi pariwisata oleh masyarakat sekitar lokasi pariwisata tentunya akan menambah penghasilan masyarakat dan meningkatkan kesejahteraan masyarakat lokal.

Terjadi gempa di pulau lombok yang berpusat di Kabupaten Lombok Timur dan Lombok Utara sebesar 7.0 dan 6.4 dan beberapa kali gempa susulan pada bulan agustus 2018 menyebabkan banyak wisatawan internasional dan lokal yang keluar dari pulau lombok 
termasuk meninggalkan tempat pariwisata yang ada di Kabupaten Lombok Tengah karena rasa trauma akibat gempa yang menelan ratusan korban jiwa. Akibat terjadinya gempa tersebut tentunya kegiatan pariwisata sedikit menurun dan berkurangnya wisatawan yang datang berkunjung di pulau lombok khususnya di Kabupaten Lombok Tengah.

Pasca gempa di pulau lombok tentunya Pemerintah Kabupaten Lombok Tengah harus berupaya bagaimana perannya agar wisatawan lokal dan mancanegara datang kembali berkunjung di pulau lombok khususnya di Kabupaten Lombok Tengah. Dari berbagai permasalahan yang diuraikan sehingga menarik perhatian peneliti untuk meneliti bagaimana "Peran Pemerintah Kabupaten Lombok Tengah Dalam Kegiatan Promosi Pariwisata Pasca Gempa Lombok"

\section{METODE PENELITIAN}

Penelitian ini tergolong pada tipe penelitian deskriptif dengan pendekatan kualitatif. Menurut Moleong (2011:6) penelitian kualitatif bermaksud untuk memahami fenomena tentang apa yang dialami oleh subyek penelitian misalnya, perilaku, persepsi, motivasi, tindakan, dll secara holistik, dan dengan cara deskriptif dalam bentuk kata-kata dan bahasa pada suatu konteks khusus yang alamiah dan dengan memanfaatkan berbagai metode ilmiah.

Pengumpulan data dilakukan dengan teknis observasi, wawancara, dan dokumentasi. Teknis analisis data yang digunakan meliputi pengumpulan data, reduksi data, penyajian data, kemudian menarik kesimpulan. Keabsahan data yang digunakan adalah teknis triangulasi sumber.

\section{HASIL DAN PEMBAHASAN}

\section{Peran Pemerintah Kabupaten Lombok Tengah Dalam Kegiatan Promosi Pariwisata Pasca Gempa Lombok}

Pemerintah Kabupaten Lombok Tengah sesuai dengan asas otonomi daerah memberikan kewenangan, tugas dan fungsi kepada Dinas Pariwasata dan kebudayaan Kabupaten Lombok Tengah untuk malakukan perencanaan, pengendalian, pengawasan, dan pengorganisasian di bidang pariwisata. Adapun beberapa kawasan pariwisata yang di promosikan oleh Dinas Pariwisata dan Kebudayaan Kabupaten Lombok Tengah adalah sebagai berikut: Objek Wisata Alam ( Hutan/Perairan pedalaman ) : Benang Stokel, Benang Kelambu, 
Aik Bukak. Daya tariknya adalah Air Terjun, Outbond Area, Camping, Kolam renang dan keindahan Alam serat pengamatan flora dan fauna.

Objek Wisata Alam ( Bahari ) : Pantai Gerupuk, Pantai Awang, Pantai An, Pantai Seger, Pantai Kuta, Selong Belanak, Pantai Mawi, Pantai Tomang, Pantai Are Guling, Pantai Pengatap, Rowok, Torok Aik Belek, Pantai Mawun. Daya Tarik dari pantai-pantai di Lombok Tengaht tersebut selain pasir putihnya, juga perbukitan, ombak untuk serving, sunset, perkampungan nelayan, budidaya ikan kerapu, budi daya mutiara, pasar ikan tradisional dan terumbu karang.

Objek Wisata Alam ( Geologi dan Vulkanologi ) : Goa Bengkang, Goa Pengembur, Gunung Rinjani, Batu Rijan. Gunung Rinjani sangat terkenal sebagai objek wisata. Aktivitas yang bisa dilakukan adalah Trekking, Pengamatan Flora Langka, Pengamatan Fauna langka, Photografi, Mancing di danau dan bisa juga dipakai untuk wisata religi. Objek Wisata Budaya ( Peninggalan Sejarah ) : Dusun Sade, Dusun Nde adalah rumah tradisional, kampung tradisional, tipologi pemukiman suku sasak, kesenian daerah dan upacara adat. Mesjid Kuno Rembitan, Mesjid Gunung Pujut adalah mesjid kuno, tipologi Pemukiman Suku Sasak dan Upacara Agama. Makam Nyatok, Makam Ketak, Makam Serewe adalah makam Tokoh Agama Islam dan Makam Raja Pejanggik.Aktivitas wisata yang bisa dilakukan adalah belajar menenun, photografi, wisata ziarah, pengamatan upacara agama dan penelitian.

Objek Wisata Buatan ( Festival Khusus) : Peresean, Rudat, Oncer, Gandrung, Gandrung, Amak Abir, Bau Nyale, Gendang Belek, Cilokaq, Menting Lelakaq, Pagelaran Zikir Madani. Sanggar Rinjani, Jangger, Ngorek, Jejaranan, Tambur, Genggong, Drama Sakral, Cupak Grantang, Wayang KUlit, Rudat, Macapat, Gansing, Selodor, Engrang, Pencak, Layang-layang, Main Karet. Salah satu tugas dan fungsi yang harus dilakukan oleh Dinas Pariwisata dan Kebudayaan Kabupaten Lombok Tengah adalah melaksanakan kegiatan promosi pariwisata. Setelah terjadinya gempa sebesar 7.0 Skala likter di pulau lombok banyak wisatawan yang keluar dan pergi dari pulau lombok karena akibat gempa yang terjadi.

Dinas Pariwisata dan Kebudayaan Lombok Tengah menyadari hal tersebut, sehingga memperbaiki sarana dan prasarana yang rusak akibat gempa dan juga memberikan sosialisasi dan edukasi pada masyarakat agar segera berbenah dan tidak trauma berkepanjangan terhadap gempa. Dinas Pariwisata dan Kebudayaan Kabupaten Lombok Tengah juga melakukan sosialisasi pada pengelola wisata alam maupun buatan agar memberikan rasa nyaman kepada wisatawan yang berkunjung dan tetap waspada dan memperhatikan keselamatan para 
pengunjung wisatawan. Seperti yang di ungkapkan oleh Kepala Dinas Pariwisata dan Kebudayaan Pariwisata Kabupaten Lombok Tengah, bahwa:

"Setelah terjadinya gempa, kami mulai berbenah dan melakukan pengecekan terhadap tempat wisata baik wisata alam maupun wisata buatan yang ada di Kabupaten Lombok Tengah apakah ada yang rusak, baik itu dari sarana dan prasarana penunjang maupun wisatanya itu sendiri. Selain itu kami memberikan sosialisasi kepada masyarakat dan pengelola tempat wisata agar memberikan rasa nyaman dan memperhatikan keamanan pengunjung wisatawan. Kami juga tetap mempromosikan seperti biasa baik itu melalui media cetak seperti koran maupun media elektronik seperti koran dan tv"

Dari hasil wawancara tersebut dapat di ketahui bahwa sesuai dengan peran dan fungsinya setelah terjadi gempa 7.0 Skala likter di pulau lombok, Dinas Pariwisata dan kebudayaan Kabupaten Lombok Tengah mulai berbenah dengan melakukan pengecekan kepada seluruh tempat wisata yang ada di Kabupaten Lombok Tengah, baik itu wisata alam maupun wisata buatan agar diketahui apakah ada yang rusak baik itu objek wisatanya maupun sarana dan prasarana penunjang atraksi wisata.

Selanjutnya Dinas Pariwisata dan Kebudayaan Kabupaten Lombok Tengah juga juga memberikan sosialisasi kepada masyarakat dan pihak pengelola objek wisata untuk tetap waspada dan memperhatikan kenyamanan dan keamanan wisatawan yang berkunjung agar wisatawan tersebut datang berkunjung di masa yang akan datang. Selain kepala Dinas Pariwisata dan Kebudayaan Lombok Tengah Peneliti juga melakukan wawancara dengan Kepala Bidang Pariwisata Kabupaten Lombok Tengah yang menyatakan bahwa:

"Kegiatan promosi pariwisata yang kami lakukan tetap seperti biasa sesuai dengan tugas, fungsi serta kewenangan kami, kami melakukan promosi baik menggunakan media cetak seperti mading, koran, baliho dan juga kami menggunakan media elektronik seperti internet, blogspot atau website maupun televisi, itu yang kami lakukan selain itu kami juga memperbaiki dan mengembangkan objek wisata alam maupun buatan agar semakin menarik untuk di nikmati oleh para pengunjung wisatawan. Yang berbeda setelah terjadinya gempa, kami melakukan pengecekan dan sosialisasi pada para pengelola wisata alam maupun wisata buatan agar memperhatikan keamanan dan kenyamanan pengunjung wisatawan"

Dari hasil wawancara tersebut dapat diketahui bahwa kegiatan promosi pariwisata yang dilakukan oleh Dinas Pariwisata dan Kebudayaan Kabupaten Lombok Tengah dilakukan 
berdasarkan tugas, fungsi dan kewenangannya dimana mereka melaksanakan promosi menggunakan media cetak dan elektronik. Tetapi ada sedikit perbedaan setelah terjadinya gempa lombok dimana Dinas Pariwisata dan Kebudayaan Kabupaten Lombok Tengah melakukan sosialisasi dan pengecekan sarana dan prasarana untuk memastikan keamanan ddan kenyaman para pengunjung wisata alam maupun wisata buatan yang ada di Kabupaten Lombok Tengah. Pegawai Dinas Pariwisata dan Kebudayaan kabupaten Lombok Tengah juga mengungkapkan bahwa:

"Selain mempromosikan lewat media cetak seperti koran, baliho ataupun mading, dan media elektronik seperti blog dan website resmi dari Dinas Pariwisata dan Kebudayaan Kabupaten Lombok Tengah kami juga mengadakan even festival budaya, untuk memperkenalkan budaya dan adat istiadat sasak di Kabupaten Lombok Tengah. Kami melakukan festival budaya "bau nyale" misalnya kegiatan itu juga akan menarik perhatian wisatawan yang datang berkunjung ke Kabupaten Lombok Tengah dan kami juga mengadakan festival kesenian adat sasak seperti gendang belek dan desa adat yaitu desa sade yang akan menarik wisatawan mancanegara dan nasional untuk datang berkunjung di Kabupaten Lombok. Setelah terjadinya gempa promosi tetap kami lakukan dan kami juga mengecek dan memperbaiki sarana dan prasarana yang rusak akibat gempa lombok"

Dari hasil wawancara di atas dapat diketahui bahwa Dinas Pariwisata dan Kebudayaan Kabupaten Lombok Tengah sesuai dengan peran dan kewenangannya melaksanakan promosi wisata menggunakan media cetak seperti koran, baliho ataupun mading dan media elektronik seperti blog dan website resmi dari Dinas Pariwisata dan Kebudayaan Kabupaten Lombok Tengah selain itu juga Dinas Pariwisata dan Kebudayaan Kabupaten Lombok Tengah mengadakan fistival budaya sasak, untuk memperkenalkan budaya dan adat istiadat sasak di Kabupaten Lombok Tengah. Hal tersebut dilakukan karena festival budaya sasak sepert festival "bau nyale" yaitu penangkapan binatang laut kecil seperti ulat yang bisa dimakan. Kegiatan itu juga akan menarik perhatian wisatawan yang datang berkunjung ke Kabupaten Lombok Tengah dan juga pemerintah mengadakan festival kesenian adat sasak seperti gendang belek dan desa adat yaitu desa sade yang akan menarik wisatawan mancanegara dan nasional untuk datang berkunjung di Kabupaten Lombok. Setelah terjadinya gempa promosi tetap dilakukan seperti biasa dan malah setelah gempa pemerintah makin gencar mempromosikan pariwisata yang ada di Kabupaten Lombok Tengah. 
Dari hasil penelitian dapat disimpulkan bahwa Peran Dinas Pariwisata dan Kebudayaan Kabupaten Lombok Tengah dalam Promosi Pariwisata Pasca Gempa lombok tetap dilaksanakan berdasarkan fungsi dan kewenangan yang dimiliki yang berlandaskan otonomi daerah yaitu mempromosikan melalui iklan media cetak dan online serta elektronik dan juga mengadakan festival budaya sasak atau lombok kepada para pengunjung wisatawan agar merasa senang menikmati seluruh atraksi wisata yang di tampilkan di Kabuputen Lombok Tengah. Adapun beberapa festival yang diadakan oleh Dinas Pariwisata dan Kebudayaan Kabupaten Lombok Tengah adalah sebagai berikut:

\section{Festival "Bau Nyale" \\ 2. Festival Gendang Beleq \\ 3. Festival Adat Peresean \\ 4. Festival Desa Adat "Desa Sade" \\ 5. Festival Pameran Budaya Adat Sasak}

Festival ini tentunya bertujuan untuk menarik perhatian wisatawan lokal maupun mancanegara untuk datang kembali berkunjung di Kabupaten Lombok Tengah sehingga meninngkatkan Pendapatan Daerah Kabupaten Lombok Tengah.

\section{Faktor Penghambat Peran Pemerintah Kabupaten Lombok Tengah Dalam Kegiatan Promosi Pariwisata Pasca Gempa Lombok}

Dalam kegiatan promosi pariwisata yang dilaksanakan oleh Dinas Pariwisata dan Kebudayaan Kabupaten Lombok Tengah berdasarkan fungsi dan kewenangannya berlandaskan otonomi daerah, Dinas Pariwisata dan Kebudayaan Kabupaten Lombok Tengah melakukan promosi dalam bentuk iklan baik di media cetak maupun elektronik, serta mengadakan even yaitu festival budaya adat suku sasak agar menarik perhatian wisatawan yang datang berkunjung. Dalam pelaksanaan promosi Pariwisata yang ada di Kabupaten Lombok Tengah tentunya Dinas Pariwata tetap menghadapi faktor penghambat atau masalah yang terjadi antara lain sebaga berikut:

1. Masih kurangnya pihak ketiga atau pihak swasta yang terlibat dalam pengembangan atau promosi serta pengelolaan pariwisata yang ada di Kabupaten Lombok Tengah, sehingga menyebabkan beberapa tempat wisata kurang begitu terkenal atau berkembang karena sarana 
dan prasarana yang masih kurang karena sumber pendanaan hanya dari Dinas Pariwisata dan Kebudayaan Kabupaten Lombok Tengah.

2. Lemahnya Koordinasi SKPD Salah satu hambatan untuk menjalankan program-program pemerintah dewasa ini adalah kurangnya koordinasi antar SKPD dan lemahnya koordinasi antar SKPD ini terkait dalam penyelenggaran promosi objek pariwisata juga menjadi kendala eksternal yang dihadapi oleh Dinas Pariwisata Kabupaten Lombok Tengah.

3. Keterbatasan Anggaran menjadi salah satu faktor penghambat juga dalam kegiatan promosi pariwisata di Kabupaten Lombok Tengah. Karena masih kurangnya pihak swasta yang terlibat dalam promosi dan pengelolaan pariwisata menyebabkan pariwisata yang tidak begitu terkenal tidak mendapatkan anggaran yang banyak untuk mengembangkan wisata tersebut.

\section{PENUTUP}

Dinas Pariwisata dan Kebudayaan Kabupaten Lombok Tengah adalah salah satu satuan perangkat daerah yang bertugas serta memiliki kewenangan untuk melaksanakan urusan pemerintahan Kabupaten Lombok Tengah dalam bidang budaya dan pariwisata berdasarkan asas otonomi daerahnya. Yaitu mengembangkan dan mempromosikan potensi pariwisata yang ada di Kabupaten Lombok Tengah.

Salah satu tugas dan fungsi yang harus dilakukan oleh Dinas Pariwisata dan Kebudayaan Kabupaten Lombok Tengah adalah melaksanakan kegiatan promosi pariwisata. Setelah terjadinya gempa sebesar 7.0 Skala likter di pulau lombok banyak wisatawan yang keluar dan pergi dari pulau lombok karena akibat gempa yang terjadi.

Dinas Pariwisata dan kebudayaan Kabupaten Lombok Tengah mulai berbenah dengan melakukan pengecekan kepada seluruh tempat wisata yang ada di Kabupaten Lombok Tengah, baik itu wisata alam maupun wisata buatan agar diketahui apakah ada yang rusak baik itu objek wisatanya maupun sarana dan prasarana penunjang atraksi wisata.

Selanjutnya Dinas Pariwisata dan Kebudayaan Kabupaten Lombok Tengah juga juga memberikan sosialisasi kepada masyarakat dan pihak pengelola objek wisata untuk tetap waspada dan memperhatikan kenyamanan dan keamanan wisatawan yang berkunjung agar wisatawan tersebut datang berkunjung di masa yang akan datang. Peran Dinas Pariwisata dan Kebudayaan Kabupaten Lombok Tengah dalam Promosi Pariwisata Pasca Gempa lombok tetap dilaksanakan berdasarkan fungsi dan kewenangan yang dimiliki yang berlandaskan 
otonomi daerah yaitu mempromosikan melalui iklan media cetak dan online serta elektronik dan juga mengadakan festival budaya sasak atau lombok kepada para pengunjung wisatawan agar merasa senang menikmati seluruh atraksi wisata yang di tampilkan di Kabuputen Lombok Tengah. Adapun beberapa festival yang diadakan oleh Dinas Pariwisata dan Kebudayaan Kabupaten Lombok Tengah adalah sebagai berikut:

\section{Festival "Bau Nyale"}

\section{Festival Gendang Beleq}

\section{Festival Adat Peresean}

\section{Festival Desa Adat "Desa Sade"}

\section{Festival Pameran Budaya Adat Sasak}

Festival ini tentunya bertujuan untuk menarik perhatian wisatawan lokal maupun mancanegara untuk datang kembali berkunjung di Kabupaten Lombok Tengah sehingga meninngkatkan Pendapatan Daerah Kabupaten Lombok Tengah.

1. Dinas Pariwisata dan Kebudayaan Kabupaten Lombok Tengah harus gencar melakukan promosi di pihak swasta agar mampu mengembangkan sektor pariwisata di Kabupaten Lombok Tengah.

2. Dinas Pariwisata harus mengelola Anggaran dengan baik agar semua objek wisata di Kabupaten Lombok Tengah bisa di promosikan dan di kembangkan dengan efektif.

3. Sebaiknya Dinas Pariwisata dan Kebudayaan Kabupaten Lombok Tengah harus mempromosikan pariwisata dengan pihak swasta agar bisa membuka potensi wisata yang lebih besar di Kabupaten Lombok Tengah. 
Journal of Government and Politics (JGOP) Vol. 1 No. 2 Desember 2019 Hal. 100-111

\section{DAFTAR PUSTAKA}

Desky. 1999. Pengantar Biro Perjalanan Wisata. Yogyakarta: PT. Adicipta.Karya Nusa.

Fandy Tjiptono. 2001. Strategi Pemasaran. Yogyakarta: Andy Offset

Freddy Rangkuti. 2002. The Power of Brands: Teknik Mengelola Brand Equitydan Strategi Pengembangan Merek. Jakarta: Gramedia Pustaka Utama

Freddy Rangkuti. 2003. Measuring Customer Satisfaction. Jakarta: GramediaPustaka Utama

Freddy Rangkuti. 2009. Strategi Promosi Yang Kreatif. Jakarta: Gramedia.Pustaka Utama.

Gerlach \& Ely. 1996

Friedman, M. Marilyn. 1998. Teori Dan Praktik. Jakarta: EGC

Hari Karyono. 1997. Kepariwisataan. Jakarta: Grasindo

Oka A. Yoeti. 1996. Anatomi Pariwisata. Bandung: Angkasa

Oka A. Yoeti. 2002. Perencanaan Strategis Pemasaran Daerah Tujuan Wisata. Pradnya Paramita : Jakarta

Ricky Febriansyah dkk, (2017) "Peran Dinas Pariwisata Dalam Mempromosikan Wisata Alam Air Terjun Km 18 Di Kabupaten Bulungan”, Fisip Unmul.

Soekanto, Soerjono. 2003. Teori Peranan. Jakarta: Bumi Aksara

Sugiono. (2012). Metode Penelitian Kualitatif dan R dan D. Bandung: Alfabeta.

Thoha, Miftah. 1997. Dimensi-Dimensi Prima Ilmu Administrasi Negara. Jakarta:PT. Raja Grafindo Perkasa.

Wahab, Salah. 2003. Manajemen Kepariwisataan. Jakarta: Pradnya Paramitha.

https://text-id.123dok.com/document/ozlrr12rz-visi-dan-misi-pariwisata-kabupaten-lomboktengah.html

https://idalamat.com/alamat/kantor-pemerintahan/24955/dinas-kebudayaan-dan-pariwisatakabupaten-lombok-tengah

https://lomboktengahkab.go.id/

https://lomboktengahkab.go.id/pariwisata/

https://lomboktengahkab.go.id/dinas-pariwisata/\#tab-id-1 